\title{
Effect of Corporate Governance Mechanisms on Financial Performance and Firm Value with Green Accounting Disclosure as Moderating Variables
}

\author{
Sari Kartika ${ }^{1 *}$ Wiwik Utami² \\ 1. Accounting Study Program, Mercu Buana University, Jl. Raya Meruya Selatan Kembangan West \\ Jakarta, Indonesia. \\ 2. Lecturer Faculty of Economics and Business, Mercu Buana University, Jl. Raya Meruya Selatan \\ Kembangan West Jakarta, Indonesia.
}

\begin{abstract}
This study aims to examine and analyze the effect of corporate governance mechanisms on financial performance and firm value with the green accounting disclosure as a moderating variable. The study was conducted at the hospitality sub-sector companies listed on the Indonesia Stock Exchange for the period of 20132017. Sampling is done by purposive sampling. The analytical methods used are path analysis and moderated regression analysis (MRA). The results of the research in the direct effect test show that corporate governance mechanisms that are proxy by foreign ownership and institutional ownership do not affect the financial performance and firm value. The frequency of audit committee meetings has a significant effect to financial performance and firm value. Financial performance has a significant effect to firm value. The financial performance can not mediate foreign ownership and institutional ownership to firm value. Financial performance can mediate the frequency of audit committee meetings to firm value. Green accounting disclosures have been proven to moderate (weaken) financial performance to firm value.
\end{abstract}

Keywords: corporate governance mechanisms; financial performance, firm value, green accounting disclosure

DOI: $10.7176 /$ RJFA/10-24-16

Publication date: December $31^{\text {st }} 2019$

\section{Introduction}

As the number of tourist destinations increases and tourist visits to Indonesia can be an opportunity for hospitality companies that have gone public. Companies going public can always provide financial performance information as a signal to potential investors, with the selection of the right investment can help increase firm value.

Company value is an investor's perception of the company which is often associated with stock prices. High stock prices make the value of the company high and illustrate the increased welfare of the owner. In running its business, companies are often faced with the condition of declining stock prices due to low performance, so that it can affect firm value. The following is a list of 5 companies that became top losers in trading on Indonesia Stock Exchange:

Table 1. List of Top Losers Companies (Indonesia Stock Exchange, 2017)

\begin{tabular}{|l|l|l|l|}
\hline \multicolumn{1}{|c|}{ Code } & \multicolumn{1}{|c|}{ Price (Rp) } & \multicolumn{1}{c|}{ Depression } & \multicolumn{1}{c|}{ (\%) } \\
\hline HOME & 296 & -94 & $-24,10$ \\
\hline INTD & 210 & -48 & $-18,60$ \\
\hline EMTK & 9.200 & -1.800 & $-16,36$ \\
\hline TBMS & 1.215 & -210 & $-14,74$ \\
\hline KBLV & 1.210 & -140 & $-10,37$ \\
\hline
\end{tabular}

At the beginning of trading the joint stock price index was opened at 5,768.16 per share and closed at 5,723.64 per share which showed a decrease of $0.14 \%$. Table 1 shows the lowest position occupied by companies in the hospitality sector. PT Hotel Mandarine Regency Tbk (HOME) experienced a significant decline in share prices in 2017. The share price of PT Hotel Mandarine Regency Tbk (HOME) fell by $24.10 \%$ at a price of Rp. 296 per 
share. This is due to a decrease in the company's net profit by $160.83 \%$. The reason for the decline in net profit was due to provision fees that the company had to pay due to changes and additions to loans from the banks.

Firm value will be high if it can implement good corporate governance mechanisms. The corporate governance mechanism is a process or structure used by corporate organs to increase business success and corporate accountability by taking into account other solder interests based on legislation and ethical values, Adrian (2012).

Empirical evidence from previous research shows that foreign ownership has an effect on firm value (Khouri, et.al (2004); Aydin, et.al (2007). However, research conducted by Kristie and Robin (2016) shows the results that foreign ownership does not affect firm value.

The research conducted by Suhartanti, et. al (2015) and Vitalia, et.al (2016) shows that institutional ownership has a positive effect on firm value. In contrast to the results of research conducted by Jennings (2002), it shows that institutional ownership does not affecton firm value.

Dezoort et.al (2002), Coleman (2007), Bouaziz and Triki (2012) in their research show the frequency of audit committee meetings influences to firm value. Whereas research of Yahya, et.al (2012) shows the results that the frequency of audit committee meetings does not affect financial performance in increasing firm value.

Investors can give full trust to companies that have good corporate value in order to produce financial performance in accordance with the goals and desires of their owners. Financial performance that is measured using return on assets (ROA) can describe the extent to which the ability of assets owned by the company to generate profits, Eduardus (2010).

Agus (2017) in his research showed the results that corporate governance has an effect on company value and ROA can mediate corporate governance on firm value. Furthermore, the research conducted by Ratih (2011) which shows the results that corporate governance has no effect on firm value and ROA cannot mediate corporate governance on firm value. While research conducted by Meilinda (2015) and Thaharah (2016) shows that good corporate governance has an effect on firm value but ROA cannot mediate corporate governance on firm value.

To be able to survive, grow and maintain business success, the company must pay attention to green accounting disclosures.Green accounting is one of the contemporary concepts in accounting that support the green movement in the company or organization by recognizing, quantifying, measuring and disclosing the contribution of the environment to the business process, Bell and Lehman (1999).

Research conducted by Ayu and Ida (2014) shows that voluntary disclosure of the environment can moderate the effect of financial performance on firm value. While Muhammady (2012) in his research shows that environmental disclosure does not affect the value of the company.

Based on this background there are phenomena and the existence of inconsistencies from the results of previous studies (research gaps) that occur in factors that affect financial performance and corporate value. This makes the writer interested in analyzing and reviewing the factors that affect financial performance and firm value by adding green accounting disclosures as a moderating variable. So that the researchers intend to conduct research with the title Influence of Corporate Governance Mechanism on Financial Performance and Firm Value with Green Accounting Disclosures as Moderating Variables.

\section{Literature Review}

\subsection{Foreign Ownership on the Financial Performance.}

Foreign ownership in a company is a party that is considered a concern for improving corporate governance. Foreign ownership of the shares of a company is expected to provide confidence to investors that management will not manipulate, embezzle or invest funds invested by investors into unprofitable projects. Therefore, management must further improve the company's financial performance due to the supervision of these foreign investors. But Yulius, et. al. (2013) in his research stated that foreign ownership had an effect on financial performance. This is because foreign parties who invest have a good management system, technology, innovation, expertise and marketing so that it can bring a positive influence to the company.

\subsection{Institutional Ownership on the Financial Performance}

Institutional ownership has an important role in minimizing agency conflict that occurs between shareholders and managers (Jensen and Meckling, 1976). Institutional ownership will encourage an increase in optimal 
supervision of financial performance because institutional investors have a better ability to monitor management actions so that this situation makes company management more careful in making decisions. Financial performance can provide satisfactory results if institutional investors are able to harmonize the interests of management and the interests of other stakeholders. As explained in the stewardship theory that the steward will try to work together for the common good to achieve common goals. The results of Angri's research, et.al (2016) support the concept that shows institutional ownership influences financial performance because institutional ownership is an outsider of management who has the power to monitor.

\subsection{Frequency of Audit Committee Meetings on Financial Performance}

Financial performance can be monitored by the audit committee. The audit committee is responsible to the board of commissioners because the audit committee is an extension of the board of commissioners to assist the task of carrying out the oversight function of the financial reporting process, risk management, the implementation of the audit of corporate governance implementation in the company. The audit committee needs to conduct audit committee meetings consistently so that financial performance can achieve the company's goals. However, research from Yahya, et. al (2012) shows that the frequency of meet-audit committee does not affect financial performance. If the quantity of audit committee meetings is not accompanied by quality, the frequency of meetings of audit committee meetings becomes ineffective and cannot affect performance. This result is refuted by the research of Bouaziz and Triki (2012) and Aryan (2015) which state that the frequency of audit committee meetings can affect company performance. According to Bouaziz and Triki (2012), the frequency of audit committee meetings shows the activity of the audit committee in implementing and controlling the course of good corporate governance to achieve maximum financial performance.

\subsection{Foreign Ownership on Firm Value.}

Foreign ownership as a steward will try to work together for mutual interests to achieve common goals. Effective monitoring can contribute to improving financial performance so that it can increase the value of the company. Firm value is an investor's perception of the company, which is often associated with stock prices. Companies with a greater percentage of foreign ownership can increase firm value. Inconsistencies between theories have occurred with the results of research by Kristie and Robin (2016) which show that foreign ownership does not affect the firm value because foreign ownership often experience asymmetry information. While research conducted by Khouri, et. al (2004), Aydin, et. al, (2007) shows that foreign ownership has a significant positive effect on firm value. These results indicate that foreign investors can monitor the work of the company's management properly and increase the company's value consistently.

\subsection{Institutional Ownership on Firm Value.}

The company will try to make public transparency to increase the firm value. Institutional ownership has an important role in minimizing agency conflict because institutional investors can control opportunistic behavior by management. Institutions will monitor financial performance optimally so that management can avoid behavior that is detrimental to the principal. Thus the stock price rises and the value of the company will increase. The research results of Suhartanti, et. al (2015) and Vitalia, et. al (2016) state that institutional ownership has a positive effect on firm value. With the presence of strong controls, management can anticipate the possibility of bankruptcy.

\subsection{Frequency of Audit Committee Meetings on Firm Value}

High firm value is inseparable from the role of the audit committee. The audit committee was formed as an effort to improve the way of management, especially the way of management oversight which will be a liaison between the management of the company and the board of commissioners and other external parties. This is in accordance with Kep.29 / PM / 2004, stating that the board of commissioners forms a committee that carries out the task of overseeing the management of the company called the audit committee. Audit committee meetings are an opportunity for management and external auditors to convey problems or findings to achieve company goals. The more frequent the audit committee meeting is, the more detailed the discussion of the matters discussed. Thus management can make improvements in order to raise stock prices that can affect the firm value. Research conducted by DeZoort, et.al. (2002), Coleman (2007) supports the concept above which shows that the frequency of audit committee meetings has a significant positive effect on firm value because corporate governance controls in increasing company value can be reflected in the frequency of meetings held 


\subsection{Financial Performance on Firm Value.}

Improving the company's financial performance is a must for companies to remain attractive to investors so that the firm value increases. If the company is able to provide transparent, complete and clear information as a tool for management accountability to investors, it can reflect a good performance of the company. Information provided by the company will be captured by investors as a signal as explained in signaling theory. The investor will catch the signal given by looking at the return given by the company. Maximum return will be obtained if the company is able to increase share prices which will provide prosperity for shareholders. This situation is a picture of the position of the firm value. According to the results of the research by Obradovich, et. al. (2013) and Wiwik, (2015) shows that financial performance has an effect on firm value.

\subsection{Financial Performance Mediates Foreign Ownership on Firm Value}

Good financial performance can increase stock prices so that the company's value is high. The high firm value can indicate shareholder prosperity which encourages investors to invest through the purchase of shares. Corporate governance develops based on stewardship theory, which is working together to manage and monitor the company in accordance with applicable rules and regulations to increase firm value. The results of research conducted by Ratih (2011), Meilinda (2015) and Thaharah (2016) show that financial performance cannot mediate the relationship of foreign ownership to firm value. The reasons for this are due to geographical barriers and differences in language, which creates obstacles in monitoring. While Yulius's research, et. al. (2013) shows that foreign ownership has an effect on financial performance and Heder, et. al (2017) shows that financial performance has an effect on firm value. This shows that indirectly with the presence of foreign ownership, the financial performance is more monitored and can provide good results to raise stock prices which have an impact on the value of the company

\subsection{Financial Performance Mediates Institutional Ownership on Firm Value}

Financial performance measured using ROA is a factor that needs to be considered in generating profits to increase the value of the company so that the welfare of stakeholders in the company can be measured by the high firm value. Institutional ownership can help reveal management information of a company in the annual report as a form of transparency to stakeholders. The better financial performance can describe the achievement of firm value. The concept above is inconsistent with the results of research by Ratih (2011), Meilinda (2015) and Thaharah (2016) which states that financial performance cannot mediate institutional ownership of firm value. While the research conducted by Agus (2017) shows that institutional ownership has an effect on the firm value by using financial performance as an intervening variable.

\subsection{Financial Performance Mediates Frequency of Audit Committee Meetings on Firm Value}

Financial reports that have high credibility can attract potential investors to invest in the company. The achievement of the audit committee function influences transparency on the financial performance that can be trusted so that it can increase the firm value. In carrying out its duties and responsibilities the audit committee must hold meeting meetings at least 4 times in one year in accordance with the guidelines of the audit committee charter. The more often held meetings, the audit committee more easily controls the company's financial performance.

The results of Bouaziz and Triki (2012) and Aryan (2015) who support the concept above and state that the frequency of audit committee meetings influences financial performance. Good financial performance can provide a good news signal for potential investors and can increase the value of the company.

\subsection{Green Accounting Disclosure Moderates Financial Performance on Firm Value}

The concept of the Triple Bottom Line (People, Planet, and Profit) or 3P that was popularized by Elkingkton (1997) can be applied to companies so that they can survive (going concern). At present the company must pay attention and be involved in fulfilling the welfare of the community which is reflected in the social aspects (people) and contributes actively in preserving the environment (planet). Investors are very fond of information that is transparent and complete as their signal to decide on an investment. The results of research conducted by Ayu and Ida (2014); Erna, et.al (2017) on voluntary disclosure of the environment proved to be able to moderate the effect of financial performance on firm value.

Based on the study of theory and the results of previous research, researchers can create framework of thought logically for understanding the relationship between corporate governance mechanisms, company performance, 
company value and green accounting disclosures. The framework of thought in this study is as follows:

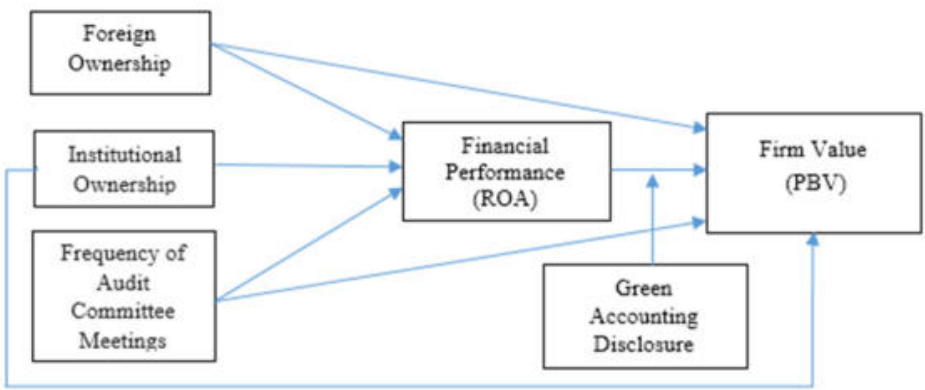

Figure 1. Thinking Framework

\subsection{Hypothesis}

In this study the hypotheses were made as follows:

H1 : Foreign ownership has a positive effect on the company's financial performance

H2 : Institutional ownership has a positive effect on the company's financial performance

H3 : The frequency of audit committee meetings has a positive effect on the company's financial performance

H4 : Foreign ownership has a positive effect on firm value.

H5 : Institutional ownership has a positive effect on firm value.

H6 : The frequency of audit committee meetings has a positive effect on firm value.

H7 : Company performance has a positive effect on firm value

H8 : Foreign Ownership through financial performance has a positive effect on firm value.

H9 : Institutional Ownership through financial performance has a positive effect on firm value.

H10 : Frequency of audit committee meetings through financial performance has a positive effect on firm value.

H11 : Green accounting disclosure can be a moderate of financial performance against firm values

\section{Methodology}

This research was conducted in less than one year, so the development method used was cross-sectional with a post ex facto post research design. The design of the post ex facto was approved when the discussion was being carried out on the subject. The population used is the hospitality sector with sampling using purposive sampling so that 9 companies were obtained for 5 years $(n=45)$.

The firm value in this study is used as the dependent variable measured using Price book value (PBV). The PBV calculation formula refers to Sukirni (2012) as follows:

$$
\text { PBV }=\frac{\text { Manket price per share }}{\text { Book value per share }} \times 100 \%
$$

For the independent variables used include:

a. Foreign Ownership

The measurement of the proportion of foreign ownership refers to Farooqueet. et.al. (2007) with the following formula:

$$
\text { Foreign Dwnership }=\frac{\sum \text { foreign per share }}{\sum \text { outstancing share capital }} x 100 \%
$$

b. Institution Ownership

Measurement of institutional ownership refers to Angriet.al (2016) with the following formula:

$$
\text { Institution Ownership }=\frac{\sum \text { institution per share }}{\sum \text { outstanding share capital }} x 100 \%
$$

c. Frequency of Audit Committee Meetings

Measurement refers to $\operatorname{Djoko}(2010)$ with the following formula:

$$
\mathrm{FACM}=\sum \text { meetings conducted in } 1 \text { year }
$$


This study uses financial performance which is proxied by return on assets (ROA) as an intervening variable.

The ROA formula refers to Sudana (2011: 22) as follows:

$$
\text { ROA }=\frac{\text { Haming Atter lax }}{\text { Total Asset }}
$$

Green accounting disclosure is used as a moderating variable. Measurements refer to the GRI-G3 based on a comparison between the disclosure index on the environmental indicators of each company and the total environmental aspects. So that it can be formulated as follows:

$$
\text { GADIj }=\frac{\sum \times i j}{n j} \times 100 \%
$$

Information:

GADIj = Green Accounting Disclosure Index company $\mathrm{j}$

$\sum \mathrm{Xij} \quad=$ number of items disclosed

nj $\quad=$ number of items in the environmental aspect

The method of data analysis in this study uses path analysis (Path Alanysis) and Moderated Regression Analysis (MRA). So that the formula is obtained as follows:

$\mathrm{ROA}=\alpha+\beta_{1} \mathrm{X}_{\mathrm{FO}}+\beta_{2} \mathrm{X}_{\mathrm{IO}}+\beta_{3} \mathrm{X}_{\mathrm{FMKA}}+\varepsilon$

$\mathrm{PBV}=\alpha+\beta_{1} \mathrm{X}_{\mathrm{FO}}+\beta_{2} \mathrm{X}_{\mathrm{IO}}+\beta_{3} \mathrm{X}_{\mathrm{FMKA}}+\beta_{4} \mathrm{ROA}+\varepsilon$

$\mathrm{PBV}=\alpha+\beta_{1} \mathrm{ROA}+\beta_{2} \mathrm{ROA} * \mathrm{GADIj}+\varepsilon$

\section{Result}

The following are descriptive statastic test results in table 2 .

Table 2- Descriptive Statistics (processed with SPSS)

\begin{tabular}{|l|c|c|c|c|c|}
\hline & $\mathbf{N}$ & Min & Max & Mean & Std. Deviation \\
\hline PBV & 45 & .01 & 14.53 & 1.76 & 2.74 \\
\hline Foreign Ownership & 45 & .01 & .62 & .30 & .17 \\
\hline Institutional Ownership & 45 & .00 & .98 & .57 & .31 \\
\hline FACM & 45 & 1.00 & 14.00 & 4.68 & 2.66 \\
\hline ROA & 45 & .02 & 40.91 & 3.71 & 7.04 \\
\hline GADIj & 45 & .10 & .57 & .24 & .17 \\
\hline Valid N (listwis) & 45 & & & & \\
\hline
\end{tabular}

Price book value (PBV) in the hospitality sector from 2013 - 2017 was valued at 1.76 times the price of the book with a standard deviation of 2.74 times. The maximum value is owned by PT. Island Concepts Indonesia Tbk (ICON) with a share price of 14.53 times the actual price in 2013. While the minimum value is at PT. Mas Murni Indonesia Tbk (MAMI) with a stock price of 0.01 times the actual price in 2013.

Foreign ownership in 2013-2017 has an average of 3\% with a standard deviation of 17\%. The largest foreign ownership is owned by PT Bayu BuanaTbk (BAYU) in 2016 with 62\%. While the minimum value is owned by PT. Pembangunan Graha Lestari Indah Tbk (PGLI) in 2017 as much as 1\%.

Institutional ownership from 2013-2017 has an average of 57\% with a standard deviation of 31\%. The maximum value that shows the proportion of institutional ownership of $98 \%$ is owned by PT. Indonesian Paradise Property Tbk (INPP) from 2013-2017. While the minimum value is at PT. Jakarta International Hotel \& Development Tbk (JIHD) in 2013-2017 at 0\%.

The frequency of Audit Committee Meetings (FACM) throughout 2013 - 2017 had an average of 4.6 meetings with a standard deviation of 2.66 times in one year. FMKA has a maximum value of 14 meetings indicated by PT. Pembangunan Graha Lestari Indah Tbk (PGLI) in 2014. While the minimum value is at PT. Island Concepts Indonesia Tbk (ICON) only held a meeting in 2013. 
ROA throughout 2013-2017 had an average of 3.7\% with a standard deviation of $7.04 \%$. The maximum ROA value is represented by PT. Pembangunan Graha Lestari Indah Tbk (PGLI) in 2013 was 40.91\%. While the minimum value is represented by PT. Hotel Sahid Jaya International Tbk (SHID) in 2015 amounted to $0.02 \%$.

Green Accounting (GADIj) in 2013-2017 had an average of 24\% with a standard deviation of $17 \%$. The maximum value is found at PT. Jakarta International Hotel \& Development Tbk (JIHD) which made 57\% disclosures throughout 2013-2017. The minimum value of $10 \%$ is indicated by PT BayuBuanaTbk (BAYU) in 2013-2017, PT. Island Concepts Indonesia Tbk(ICON) in 2013-2015, PT. Pembangunan Graha Lestari Indah Tbk (PGLI) and PT. Hotel Sahid Jaya International Tbk (SHID) in 2013-2014.

The next stage we tested the direct effect, indirect effect and moderate using path analysis and MRA. These results are summarized in table 3 .

Table3. Summary of Path Analysis and MRA Coefficient (processed with SPSS, 2019)

\begin{tabular}{|l|l|l|l|l|l|}
\hline \multicolumn{1}{|c|}{ Regression } & Coefficient & $\begin{array}{c}\text { Standard } \\
\text { Error }\end{array}$ & \multicolumn{1}{|c|}{ t } & Sig. & Explanation \\
\hline Foreign Ownership $\rightarrow$ ROA & 1.861 & 6.445 & .289 & .774 & Not significant \\
\hline Institutional Ownership $\rightarrow$ ROA & 1.051 & 3.647 & .288 & .775 & Not significant \\
\hline FACM $\rightarrow$ ROA & 1.687 & .328 & 5.142 & .000 & Significant \\
\hline Foreign Ownership $\rightarrow$ PBV & -4.668 & 2.594 & -1.800 & .079 & Not significant \\
\hline Institutional Ownership $\rightarrow$ PBV & .526 & 1.467 & .358 & .722 & Not significant \\
\hline FACM $\rightarrow$ PBV & -.426 & .169 & -2.517 & .016 & Significant \\
\hline $\mathrm{ROA} \rightarrow \mathrm{PBV}$ & .284 & .063 & 4.530 & .000 & Significant \\
\hline $\mathrm{ROA} \rightarrow \mathrm{GADIj} \rightarrow \mathrm{PBV}$ & -.656 & .201 & -3.263 & .002 & Moderate \\
\hline
\end{tabular}

Direct effect is obtained from the results of the beta coefficient from the regression results. While the magnitude of indirect effects can be calculated by multiplying the beta coefficients of the variables passed (Ghozali, 2012). A summary of the direct effect (DE) and indirect effect(IE) is presented in the following table:

Table 4. Direct and Indirect Relations Coefficients(processed with SPSS, 2019)

\begin{tabular}{|l|c|c|c|c|c|c|c|c|}
\hline \multirow{2}{*}{\begin{tabular}{l} 
Variable \\
\multirow{2}{*}{}
\end{tabular}} & \multicolumn{2}{|c|}{$\begin{array}{c}\text { Foreign } \\
\text { Ownership }\end{array}$} & \multicolumn{2}{c|}{$\begin{array}{c}\text { Institutional } \\
\text { Ownership }\end{array}$} & \multicolumn{2}{c|}{ FMKA } & \multicolumn{3}{c|}{ ROA } \\
\cline { 2 - 10 } & DE & IE & DE & IE & DE & IE & DE & IE \\
\hline ROA & 1.861 & - & 1.051 & - & 1.687 & - & - & - \\
\hline PBV & -4.668 & 0,528 & 0,526 & 0,298 & -.426 & 0,479 & 0,284 & - \\
\hline
\end{tabular}

To test the significance of mediation can be done with an alternative approach using the bootstaping technique. The bootstraping results are as follows:

a. Foreign Ownership through ROA on PBV

Tests for the significance of the indirect effect with bootstrapping obtained true indirect effect estimates ranging from $(-1.8125)$ to $(1.2998)$ at $95 \%$ confidence intervals. Because zero contained in the confidence interval, there was no significant indirect effect at the $5 \%$ significance level. So it can be concluded that the company's financial performance cannot mediate foreign ownership of the value of the company

b. Institutional Ownership through ROA on PBV

Tests for the significance of the indirect effect with bootstrapping obtained true indirect effect estimates ranging from $(-0.9093)$ to $(1.4540)$ at $95 \%$ confidence intervals. Because zero contained in the confidence interval, there was no significant indirect effect at the $5 \%$ significance level. So it can be concluded that the company's financial performance cannot mediate institutional ownership of the value of the company

c. FACM through ROA on PBV

Tests for the significance of the indirect effect with bootstrapping obtained true indirect effect estimates ranging from $(0.0598)$ to $(1.3584)$ at $95 \%$ confidence intervals. Because zero is not included in the $95 \%$ confidence interval range, it can be said that there is a significant indirect effect at the $5 \%$ significance level. 
So it can be concluded that the company's financial performance can mediate the frequency of audit committee meetings with regard to firm value.

\section{Conclusion}

Corporate governance mechanisms that are proxied by foreign ownership and institutional ownership do not affect the financial performance and firm value. The frequency of audit committee meetings affects the financial performance and the frequency of audit committee meetings has a significant effect on the negative direction of firm value. Financial performance has a significant effect on firm value. Financial performance cannot mediate the relationship between foreign ownership, institutional ownership and firm value. However, financial performance can mediate the relationship between the frequency of audit committee meetings to firm value. And then green accounting disclosures can moderate financial performance against firm value. However, green accounting disclosure as a moderating variable can weaken financial performance against firm value.

\section{References}

A.A.Ayu T.B\& Ida, B.P.A. 2014. Moderasi Corporate Social Responsibility Terhadap Pengaruh Kinerja Keuangan Pada Nilai Perusahaan. E-Journal Akuntansi Universitas Udayana, 8(2), 136-151.

Agus, S. 2017. Pengaruh Good Corporate Governance Terhadap Nilai Perusahaan Dengan Kinerja Keuangan Sebagai Variabel Intervening. Prosiding Seminar Nasional dan Call For Paper Ekonomi dan Bisnis, Jember.

Akpan, E. 2015. Corporate Board Meeting and Company Performance: Empirical Evidence From Nigerian Quoted Companies. Global Journal of Commerce and Management Perspective.4(1), 75-82.

Al-Khouri R., A. Magableh, and H. M. Aldamen. (2004). Foreign Ownership and Firm Valuation. An Empirical Investigation. Finance India, 18(2), 779-799.

Anonim. 2004. Peraturan Nomor IX.I.5 tentang Pembentukan dan Pedoman Pelaksanaan Kerja Komite Audit (Lampiran dari Keputusan Ketua Bapepam Nomor Kep-29/PM/2004). Jakarta: Bapepam-LK.

Anonim, Undang-Undang No. 25 Tahun 2007 tentang Penanaman Modal.

Angri, W. R, Raharjo, K; Andini, R. 2016. Pengaruh Good Corporate Governance, Kepemilikan Institusional, Leverage, Independensi dan Rentabilitas Terhadap Kinerja Keuangan Perusahaan. Journal of Accounting. $2(2)$.

Aryan, A, Laith. 2015. The Relationship between Audit Committee Characteristics, Audit Firm Quality and Companies' Profitability. Asian Journal of Finance \& Accounting. 7(2), 215-226.

Aydin, N, Sayim, M; Yalama, A. 2007. Foreign Ownership and Firm Performance: Evidence from Turkey.International Research journal of Finance and Economics.2, 103-111.

Bambang, S dan Deri, R. 2013. Pengaruh Good Corporate Governance terhadap Nilai Perusahaan Melalui Corporate Social Responbility. Media Riset Akuntansi, Auditing dan Informasi. 13(1), 1-35.

Bell, F dan Lehman, G. 1999. Recent Trends in Environment Accounting: How Green Are Your Account.Accounting Forum .

Bouaziz, Z, Triki, M. 2012. The Impact of the Board of Directors on the Financial Performance of Tunisian Companies. Universal Journal of Marketing and Business Research. 1(2), 56-71.

Coleman, A. K. 2007. Corporate Governance and Firm Performance in Africa: A Dynamic Panel Data Analysis.Research Paper for the International Conference on Corporate Governance in Emerging Markets. 32 (2), 1-24.

DeZoort, F. T, Hermanson, D. R; Archambeault, D. S; Reed, S. A. 2002. Audit Committee Effectiveness: A Synthesis of the Empirical Audit Committee Literature.Journal of Accounting Literature. 21(38).

Djoko, S, Purwanto, Sari, K; Erna Setiany. (2018). Corporate Governance and Social Disclosure: A Comparative Study of Listed Hospitality Industries in South East Asia. International Journal Trade and Global Markets. 11(1/2), 21-30.

Farooque, O.A, Tony, V.Z; Keitha, D; AKM Waresul K. 2007. Corporate Governance in Bangladesh: Link Between Ownership and Financial Performance, Blackwell Publishing Ltd. Journal Compilation. 15(6), 1453-1468.

Fahmi, I. 2012. Analisis Laporan Keuangan. Bandung: Alfabeta. 
Ghozali Imam. 2012. Aplikasi Analisis Multivariate Dengan Program SPSS. Semarang: Badan Penerbit Universitas Diponegoro.

Heder, Priyadi, M.P. 2017. Pengaruh Kinerja Keuangan Terhadap Nilai Perusahaan dengan Good Corporate Governance sebagai Variabel Pemoderasi. Jurnal Ilmu dan Riset Akuntansi. 6 (7).

I Made Sudana. (2011). Manajemen Keuangan Perusahaan Teori dan Praktek. Jakarta: Erlangga.

Jennings, W. W. (2002). Further Evidence On Institutional Ownership And Corporate Value. Working Paper. US Air Force Academy.

Jhon Elkingkton. 1997. Cannibals with Forks : The Triple Botton Line of 21st Centaury Business. Oxford. UK:Capstone.

Kristie, O., \& Robin. 2016. Pengaruh Tata Kelola Perusahaan terhadap Nilai Perusahaan. Bina Ekonomi. 20(1),122.

Mardiyanti Umi, et.al. 2012. Pengaruh Kebijakan Dividen, Kebijakan Utang dan Profitabilitas terhadap Nilai Perusahaan.Jurnal Riset Manajemen Sains Indonesia (JRMSI). 3( 1). 1-17.

Meilinda, S. H. 2015. Analysis The Influence of Good Corporate Governance and Capital Structure to Firm Value With Financial Performance as Intervening Variable. MPRA Paper No. 77038.

Monks, R.A.G, Minow, N. 2011. Corporate Governance: Fifth Edition. UK: John Wiley \& Sons.

Muhammady, Faddly Akbar El. 2012. Pengaruh Kinerja Keuangan dan Corporate Social Responsibility (CSR) Terhadap Nilai Perusahaan Pada Perusahaan Manufaktur yang Terdaftar di BEI. Jurnal Manajemen Fakultas Ekonomi Universitas Gunadarma, 1

Obradovich, J, Gill, A. 2013. The Impact of Corporate Governance and Financial Leverage on the Value of American Firms.International Research Journal of Finance and Economics. 91, 1-14.

Tandelilin, Eduardus. 2010. Portofolio dan Investasi Teori dan Aplikasi. Edisi pertama. Yogyakarta : Kanisius

Thaharah Nina. 2016. Pengaruh Mekanisme Corporate Governance Dan Kinerja Keuangan Terhadap Nilai Perusahaan. Jurnal Ilmu dan Riset Akuntansi. 5(2)

Ratih, Suklimah. 2011. Pengaruh Good Corporate Governance Terhadap Nilai Perusahaan dengan Kinerja Keuangan Sebagai Variabel Intervening.Jurnal Kewirausahaan. 5(2), 18-24.

Riza, Bernandhi, Abdul, M. (2014). Pengaruh Kepemilikan Manajerial, Kepemilikan Institusional, Kebijakan Dividen, Leverage dan Ukuran Perusahaan terhadap Nilai Perusahaan. Diponegoro Journal Of Accounting. 3(1), 1-14.

Suhartanti, T, Asyik, N.F. 2015. Pengaruh Corporate Governance Terhadap Nilai Perusahaan dengan Kinerja Keuangan sebagai Variabel Moderating. Jurnal Ilmu \& Riset Akuntansi. 4(8), 1-14.

Sukirni, D. 2012. Analisis Kepemilikan Manajerial, Kepemilikan Institusional, dan Kebijakan Deviden, dan Kebijakan Hutang Terhadap Nilai Perusahaan.Accounting Analysis Journal. 1(2), 2252-6765.

Suwardjono. 2014. Teori Akuntansi Perekayasaan Pelaporan Keuangan, edisi ketiga cetakan kedelapan.Yogyakarta: BPFE Yogyakarta

Vitalia, A, Widyawati, D. 2016. Pengaruh Struktur Kepemilikan dan Profitabilitas Terhadap Nilai Perusahaan Properti Di BEI. Jurnal Ilmu dan Riset Akuntansi, 5(1), 1-20.

Widiarjo, W, Bandi; Hartoko, S. 2010.Pengaruh Ownership Retention, Investasi Dari Proceeds, dan Reputasi Auditor Terhadap Nilai Perusahaan dengan Kepemilikan Manajerial dan Institusional sebagai Variabel Pemoderasi.Simposium Nasional Akuntansi XIII, Purwokerto.

Wiwik Utami.2015. Financial Performance and the Quality of Sustainability Disclosure Based on Global Reporting Initiative: Value Relevances Study in Indonesia Stock Exchange. Mediterranean Journal of Social Sciences. 6(5), 243-248.

Yahya A.A, et.al. 2012. Board of Directors, Audit Committee Characteristics and Performance of Saudi Arabia Listed Companies. International Review of Management and Marketing. 2(4), 241-251.

Yulius, A.W., \& Yeterina, W.N. 2013. Pengaruh Struktur Kepemilikan Terhadap Profitabilitas Perusahaan Manufaktur di Indonesia. Jurnal Akuntansi dan Keuangan 15(1), 15-26. 